\title{
FAKTOR LINGKUNGAN TEMPAT TINGGAL YANG BERHUBUNGAN DENGAN BERHENTI PAKAI NARKOBA SUNTIK
}

\author{
Harvina Sawitri ${ }^{*}$ \\ Bagian Ilmu Kesehatan Masyarakat Fakultas Kedokteran \\ Universitas Malikussaleh Lhokseumawe-Aceh, 24352, Indonesia \\ *Corresponding Author: harvina.sawitri@gmail.com
}

\begin{abstract}
Abstrak
Narkotika dan obat-obatan terlarang merupakan permasalahan global saat ini. 3,3$6,1 \%$ penduduk dunia menggunakan obat-obatan terlarang. Di Indonesia 1,99 \% penduduknya menggunakan narkotika dan obat-obatan terlarang dan $7 \%$ dari jumlah tersebut merupakan pengguna narkoba suntik (penasun). Pemakaian narkoba dapat mengakibatkan bermacam-macam gangguan mental dan perilaku dan mengakibatkan terjadinya berbagai penyakit. Sedangkan pemakaian jarum suntik bergantian pada pengguna narkoba suntik dapat meningkatkan angka infeksi HIV, Hepatitis B, dan Hepatitis C. Desain penelitian ini adalah menggunakan desain potong lintang dengan mempertimbangkan variabel waktu. Analisis yang digunakan adalah analisis survival menggunakan metode Kaplan Meier untuk melihat hubungan antara variabel dependen dan independen. Sampel penelitian ini adalah 268 pengguna narkoba suntik pada Survei Penyalahgunaan Narkoba di Indonesia tahun 2008 yang dilakukan oleh Badan Narkotika Nasional. Pada lama pemakaian narkoba suntik pada responden, waktu paling sedikit adalah 3 bulan dan waktu paling lama adalah 348 bulan (29 tahun). Umur paling muda pengguna narkoba suntik adalah 15 tahun dan paling tua 44 tahun. Faktor yang berhubungan dengan berhenti pakai narkoba suntik adalah anggota keluarga tidak ada yang pakai narkoba. Tinggal bersama keluarga mempunyai peluang 1,50 kali lebih cepat untuk berhenti pakai narkoba suntik. Perlu adanya peningkatan konseling secara individu antara petugas penjangkauan dengan pengguna narkoba untuk lebih memotivasi pengguna narkoba supaya dapat merubah perilakunya dari berisiko menjadi tidak berisiko.
\end{abstract}

Kata Kunci : lingkungan tempat tinggal; narkoba; penasun 


\title{
LIVING ENVIRONMENT FACTORS RELATED TO CESSATION OF INJECTING DRUG USE
}

\begin{abstract}
Narcotics and illegal drugs is a global problem. About 3.3 to $6.1 \%$ of world population uses illegal drugs. In Indonesia, $1.99 \%$ of the population using drugs and illicit drugs and $7 \%$ of them are injecting drug users. Drug uses can lead to many mental and behavioral disorders and caused various diseases. And using drugs with needles in intravenous can increase the rate of HIV infection, Hepatitis $\mathrm{B}$ and Hepatitis C. The design of this study is use a cross-sectional design with time variable into the consideration. This analysis used survival analysis which KaplanMeier is used to see the relationship between the dependent and independent variables. The research sample is 268 injecting drug users in Indonesian Survey on Drug Abuse conducted in 2008 by BNN. At the time of injecting drug use among respondents, the time is at least 3 months and a maximum was 348 months (29 years). The youngest age of injecting drug users is 15 years old and the oldest is 44 years. Factors associated with cessation of injecting drug use is no family member who used drugs. Living with family has chances 1.50 times faster to stop injecting drug use. Need for increased counseling to individuals between the outreach workers to better motivate drug addicts in order to change the behavior of the risk to no risk.
\end{abstract}

Keyword: family environment; injecting drugs; injecting drug users 


\section{Pendahuluan}

Penyalahgunaan narkotika dan obatobatan terlarang merupakan permasalahan yang serius. Secara global, United Nations Office on Drugs and Crime (UNODC) mengestimasi tahun 2009 antara 149 sampai 272 juta orang, atau sekitar $3.3 \%$ sampai 6.1\% dari populasi usia 15-64 menggunakan obat-obatan terlarang setidaknya sekali dalam hidup mereka ${ }^{1}$. Dari hasil Survey Penyalahgunaan Narkoba di Indonesia yang dilakukan oleh BNN dan Puslitkes UI tahun 2008, sebanyak 3,1 juta sampai 3,6 juta orang atau sekitar $1,99 \%$ dari total seluruh penduduk Indonesia yang berisiko terpapar narkoba dan pada Survei Narkoba Rumah Tangga Tahun 2010, angka prevalensi penyalahgunaan narkoba meningkat yaitu sebanyak $2,4 \%$. Artinya, ada satu diantara 42 orang yang berumur 10-60 tahun yang pernah pakai narkoba minimal satu kali seumur hidup ${ }^{2}$.

Penggunaan narkoba mengakibatkan banyak dampak buruk, diantaranya dampak kriminalitas, ekonomi dan kesehatan. Dari data kasus kriminal, kasus tindak pidana narkotika meningkat dari tahun 2001-2008 di Indonesia. Pada tahun 2001, data kasus tindak pidana narkotika adalah 1.097 kasus, tahun 2004 meningkat menjadi 3.874 kasus dan tahun 2008 sebanyak 10.006 kasus $^{3}$. Estimasi kerugian biaya ekonomi akibat narkoba tahun 2008 lebih tinggi sekitar 37\% dibandingkan tahun 2004. Dengan total kerugian biaya sekitar Rp.32,4 trilyun (2008). Hasil proyeksi menunjukan kerugian biaya ekonomi akibat penyalahgunaan narkoba akan meningkat dari Rp.32,4 trilyun di tahun 2008 menjadi Rp.57,0 trilyun di tahun 2013². Pemakaian narkoba suntik mengakibatkan terjadinya berbagai penyakit. O'Brien, Day, Black, dan Dolan (2008 : 1602) ${ }^{4}$ menyebutkan di Australia, $74 \%$ dari pengguna narkoba suntik di deteksi terinfeksi hepatitis C, begitupula menurut Samuel, Doherty,
Bulterys, dan Jenison (2001)5, sedangkan pengguna narkoba suntik yang terkena Hepatitis B sebanyak $61,1 \%$.

Persentase pengguna narkoba suntik di Indonesia adalah $7 \%$ dari seluruh pengguna narkoba menurut survei di 17 provinsi tahun 2008. Populasi pengguna narkoba suntik paling banyak di provinsi DKI Jakarta (14\%), Jawa Barat (14\%), dan Jawa Timur (13\%). Pengguna narkoba suntik lebih banyak mengakibatkan dampak buruk dibandingkan pengguna narkoba narkoba jenis lainnya. Kejadian overdosis pada kelompok pengguna narkoba suntik sebanyak $28 \%$ dari semua pengguna narkoba. Pada survei di 17 provinsi di Indonesia, 38\% dari pengguna narkoba pernah melakukan tindakan kriminal, dan $58 \%$ dari mereka adalah pengguna narkoba suntik. Satu dari 5 penyalahguna pernah ditangkap pihak kepolisian terkait urusan narkoba, $47 \%$ diantara mereka adalah pengguna narkoba suntik. 13\% penyalahguna pernah dipenjara dan 31\% nya adalah pengguna narkoba suntik. Penyalahguna mengakui ada aktivitas yang terganggu akibat mengkonsumsi narkoba, misalknya tidak bersekolah atau bekerja. Mereka yang mengakui hal ini ada sebanyak $41 \%$ terutama pengguna narkoba suntik ${ }^{2}$.

Dari beberapa hasil penelitian, diketahui beberapa faktor yang mendukung berhentinya menyuntik. Faktor predisposisi adalah jenis kelamin, pengetahuan ${ }^{6}$, mempunyai pendidikan tinggi ${ }^{7}$, dan mempunyai pekerjaan8. Faktor pendukung adalah aksessibilitas terhadap pelayanan kesehatan, dukungan keluarga ${ }^{6}$, dan masih mempunyai orangtua setidaknya salah satu ${ }^{8}$. Sedangkan faktor pendorong adalah pengurangan konsumsi alkohol, tidak menggunakan inhalant, berhenti bicara dengan teman yang juga menggunakan narkoba suntik ${ }^{7}$ frekuensi menyuntik, dan jumlah narkoba yang disuntikkan ${ }^{8}$.

Penelitian mengenai determinan berhenti pakai narkoba suntik belum 
banyak dilakukan di Indonesia. Oleh karena itu, berdasarkan uraian diatas, maka akan dilakukan penelitian mengenai determinan berhenti pakai narkoba suntik pada survei penyalahgunaan narkoba yang dilakukan di 17 provinsi di Indonesia tahun 2008.

\section{Metode Penelitian}

Penelitian ini menggunakan pendekatan kuantitatif, yang menganalisis data sekunder dari studi yang dilaksanakan pada tahun 2008 di 17 provinsi di Indonesia. Desain dari penelitian ini adalah potong lintang yang mengukur variabel dependen dan independen secara bersamaan dengan mempertimbangkan variabel waktu. Populasi pada penelitian ini adalah pengguna narkoba suntik pada Survei Penyalahgunaan Narkoba di Indonesia (Studi Kerugian Ekonomi dan Sosial Akibat Narkoba, tahun 2008). Besar sampel yang akan diambil adalah seluruh sampel pengguna narkoba suntik yang berjumlah 268 orang.

Variabel dependen (tergantung) dibangun dari komponen lama pakai narkoba suntik adalah umur pertama kali pakai sampai berhenti lebih dari 3 bulan. Variabel independen (bebas) dipilih adalah faktor lingkungan tempat tinggal yang terdiri dari lingkungan tempat tinggal dan riwayat keluarga pakai narkoba. Analisis yang digunakan adalah analisis survival dengan kurva Kaplan Meier dan uji kemaknaan dengan Log rank test.

Secara umum, analisis survival adalah kumpulan prosedur statistik untuk analisis data dimana variabel outcome nya adalah waktu sampai terjadinya event (time to event). Pada saat melakukan suatu analisis survival biasanya merujuk pada variabel waktu sebagai survival time. Secara khusus merujuk suatu kejadian (event) sebagai suatu failure, sementara dalam keadaan dimana beberapa informasi mengenai individu diketahui namun tidak mengetahui dengan pasti waktu survivalnya, maka hal ini disebut sebagai censor (censoring). Untuk menilai peluang kejadian akan menggunakan regresi cox (Cox proportional hazard). Cox regression juga disebut proportional hazard model karena dibuat tanpa asumsi tentang bagaimana baseline insiden (hazard) berubah sepanjang waktu diantara saat orang tidak terpajan. Dengan cox model dimaksudkan untuk mengestimasi hazard ratio (HR), menguji hipotesa dari HR, dan melihat confidence interval $(95 \%)^{9}$.

\section{Hasil Penelitian}

Hasil yang diperoleh dari lama pakai narkoba suntik sampai berhenti pada responden, waktu paling pendek adalah 3 bulan dan paling panjang adalah 348 bulan (29 tahun). Median survival pada berhenti pakai narkoba suntik adalah 164 bulan, artinya dalam waktu pengamatan selama 164 bulan (13,6 tahun) sebanyak 50\% responden telah berhenti pakai narkoba suntik. Total subjek yang berhenti pakai narkoba suntik dalam waktu lebih sama dengan 3 bulan adalah 31,8\%, dapat dilihat pada kurva kelangsungan pemakaian narkoba suntik (gambar 1). Dari hasil tabel gambaran lingkungan tempat tinggal dan keluarga pakai narkoba, didapatkan hasil 67,2\% tinggal bersama keluarga, 32,1\% ada anggota keluarga yang pakai narkoba dan $25 \%$ dari anggota keluarga yang pakai narkoba adalah ayah.

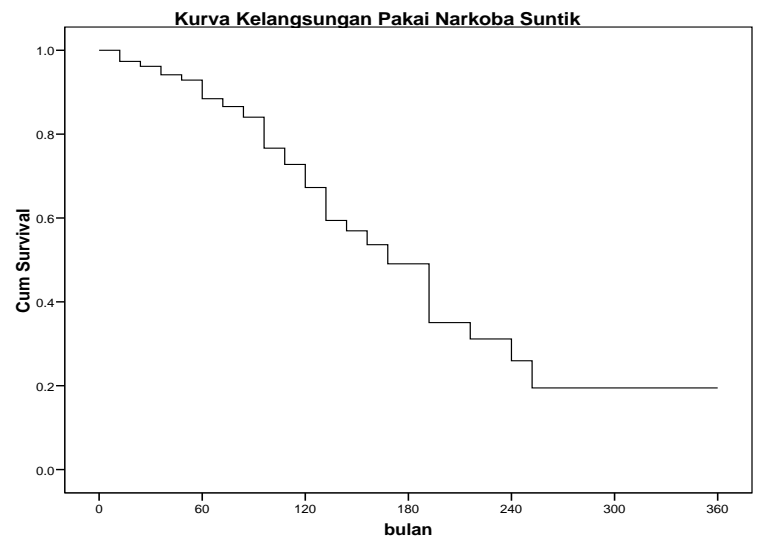

Gambar 1. Kurva Kelangsungan Pakai Narkoba Suntik 
Tabel 1. Gambaran Lingkungan Tempat

Tinggal dan Keluarga Pakai Narkoba

\begin{tabular}{lcc}
\hline \multicolumn{1}{c}{ Variabel } & $\mathbf{n = 2 6 8}$ & Persen (\%) \\
\hline Lingkungan Tempat Tinggal & & \\
Tinggal Sendiri & 88 & 32,8 \\
Tinggal bersama keluarga & 180 & 67,2 \\
\hline Keluarga Pakai Narkoba & & \\
Tidak & 182 & 67,9 \\
Ya & 82 & 32,1 \\
\hline
\end{tabular}

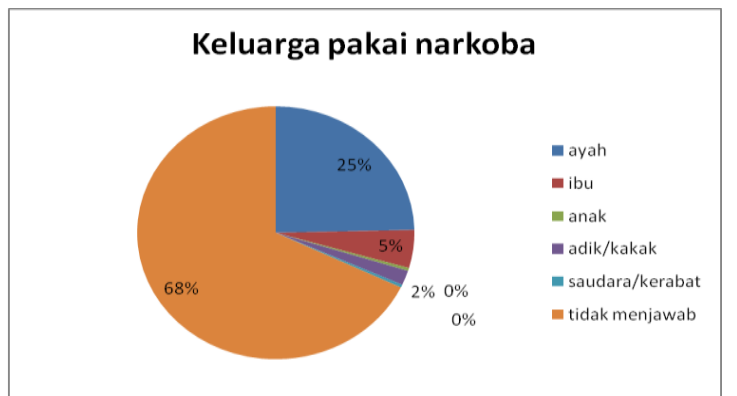

Gambar 2. Keluarga pakai narkoba
Berdasarkan analisis hubungan variabel bebas dengan waktu pakai narkoba suntik, median survival berhenti pakai narkoba suntik lebih cepat pada pengguna narkoba suntik yang tinggal bersama keluarga dan keluarga tidak pakai narkoba. Sedangkan pada kelangsungan pakai narkoba suntik lebih lama pada pengguna narkoba suntik yang tinggal sendiri dan ada anggota keluarga yang pakai narkoba.

Tabel 2. Hubungan Variabel Bebas dengan Waktu Pakai Narkoba Suntik

\begin{tabular}{lccc}
\hline \multicolumn{1}{c}{ Variabel } & $\begin{array}{c}\text { Median Survival } \\
\text { (bulan) }\end{array}$ & $\begin{array}{c}\text { Persentase Masih } \\
\text { Pakai (14 tahun) }\end{array}$ & P wald \\
\hline Lingkungan Tempat Tinggal & 184,75 & 63 & 0,71 \\
Tinggal sendiri & 152,99 & 40 & \\
Tinggal bersama keluarga & & & 0,33 \\
\hline Keluarga Pakai Narkoba & 187,30 & 63 & \\
Ya & 128,70 & 39 & \\
Tidak & & &
\end{tabular}

Berdasarkan hasil analisis hubungan faktor lingkungan tempat tinggal yang berhubungan dengan berhenti pakai narkoba suntik, tinggal bersama keluarga mempunyai peluang 1,38 kali lebih cepat untuk berhenti pakai narkoba suntik dibandingkan dengan tinggal sendiri, namun hubungannya tidak signifikan.
Pengguna narkoba suntik yang keluarganya tidak ada yang menggunakan narkoba mempunyai peluang lebih tinggi (2,19 kali) untuk berhenti pakai narkoba suntik. Keluarga pakai narkoba mempunyai hubungan yang signifikan dengan berhenti pakai narkoba 
Tabel 3.Faktor Lingkungan Tempat Tinggal yang Berhubungan dengan Berhenti Pakai Narkoba Suntik

\begin{tabular}{llcccc}
\hline \multicolumn{1}{c}{ Faktor Pendukung } & \multicolumn{2}{c}{$\begin{array}{c}\text { Berhenti Pakai Narkoba } \\
\text { Suntik (\%) } \\
\text { Berhenti Pakai }\end{array}$} & HR & HR (CI 95\%) & P log-rank \\
& Terus Pakai & & & \\
\hline $\begin{array}{l}\text { Lingkungan Tempat Tinggal } \\
\text { Tinggal sendiri }\end{array}$ & 71,6 & 28,4 & 1 & - & 0,19 \\
Tinggal bersama keluarga & 67,2 & 32,8 & 1,38 & $0,85-2,26$ & \multirow{2}{*}{0,00} \\
\hline Keluarga Pakai Narkoba & 72,1 & 27,9 & 1 & - & \\
Ya & 67,0 & 33,0 & 2,19 & $1,36-3,56$ & \\
Tidak & & & &
\end{tabular}

\section{Pembahasan}

Penelitian kuantitatif ini menggunakan data sekunder yang dikumpulkan pada pertengahan tahun 2008. Salah satu konsekuensi penggunaan data sekunder adalah terbatasnya jumlah variabel dan definisi operasional yang digunakan. Dari kerangka teori diketahui bahwa faktor kepercayaan pada Health Belief Model $^{10}$ yaitu perceived susceptibility, perceived seriousness, dan cues to action mempunyai kemungkinan berperan secara langsung terhadap berhenti pakai narkoba suntik. Namun variabel-variabel tersebut tidak tersedia dalam data survei ini.

Variabel dependen adalah lama pakai narkoba suntik yang dihitung dari umur pertama kali pakai sampai berhenti lebih sama dengan 3 bulan. Variabel ini mempunyai kemungkinan bias ingatan, karena responden hanya menjawab pertanyaan dalam kuesioner berdasarkan ingatan semata. Selain itu, Menurut Doweiko (2002)11, 90 hari (3 bulan) pascamulai terapi adalah masa rawan untuk kambuh (ingin menggunakan narkoba lagi). Penelitian ini tidak memperhatikan kekambuhan (relaps)

Faktor pendukung yang berhubungan dengan berhenti pakai narkoba suntik adalah keluarga pakai narkoba. Pada penelitian ini membuktikan bahwa pada pengguna narkoba suntik yang keluarganya tidak ada yang menggunakan narkoba, peluang untuk berhenti pakai narkoba lebih cepat.

Pada umumnya, penggunaan narkoba pertama pertama kali pada remaja disebabkan oleh kejadian yang terjadi dirumahnya, misalnya pertengkaran dalam keluarga, perceraian, dan ada salah satu orangtua yang menikah kembali. Meskipun ada anggota keluarga yang juga pakai narkoba dapat menjadi faktor yang mendorong seseorang untuk pakai narkoba ${ }^{12}$. Oleh karena itu, pada pengguna narkoba suntik yang anggota keluarganya tidak ada yang menggunakan narkoba, berhenti pakai narkoba akan lebih cepat.

Dari penelitian Soitawati (2009)6, pengguna narkoba suntik yang tidak mendapatkan dukungan keluarga atau teman memiliki risiko putus terapi metadon lebih tinggi dibandingkan dengan pengguna narkoba suntik yang mendapat dukungan keluarga atau teman. Dukungan positif dari keluarga atau teman sebaya menjadi faktor yang penting karena umumnya ketergantungan narkoba terjadi pada seseorang yang sangat erat kaitannya dengan masalah yang timbul dalam keluarga atau pergaulan dengan teman sebaya yang kurang baik. Sehingga dukungan positif yang didapatkan dari keluarga atau teman akan mampu memotivasi responden untuk tetap melanjutkan pengobatan metadon. Keterlibatan dan peran orangtua atau keluarga dalam pogram terapi metadon 
secara psikis akan mendukung pasien dalam menjalani pengobatan karena selama pengobatan dibutuhkan kerjasama dengan keluarga/teman pasien terutama terkait dengan dosis yang dibawa pulang bila pasien berhalangan datang ke klinik, atau adanya penyakit lain yang menyertai pasien yang perlu penanganan lanjut.

Keluarga juga akan membantu konselor dalam memilih program pengobatan atau rehabilitasi yang tepat untuk pengguna narkoba suntik. Mereka juga merupakan sumber informasi yang tepat untuk menanggulangi masalah psikologis yang muncul pada pengguna narkoba narkoba seperti stres, depresi, dan keinginan untuk bunuh diri sehingga pengguna narkoba suntik dapat dimotivasi agar berhenti memakai narkoba dan menjalani hidup dengan lebih baik. Alasan dan penyebab pengguna narkoba suntik menggunakan narkoba juga dapat digali dari teman dan keluarga, sehingga upaya pencegahan untuk kambuh kembali dapat diatasi. Oleh karena itu, dalam upaya perawatan dan pengobatan, keluarga harus diikutsertakan dalam proses pengobatan ${ }^{13}$.

\section{Daftar Pustaka}

1. United Nations Office on Drugs and Crime (UNODC). World Drug Report. New York: United Nation, 2011

2. BNN \& Puslitkes UI. Laporan Survei Penyalahgunaan Narkoba di Indonesia: Studi Kerugian Ekonomi dan Sosial Akibat Narkoba Tahun 2008. Jakarta : Author, 2008

3. BNN. Data Kasus Tindak Pidana Narkoba Di Indonesia Tahun 20012008. Available from www.bnn.go.id.

4. O'Brien Susannah, Day Carolyn, Black Emma, dan Dolan Kate. Injecting drugs users understanding of hepatitis C. Addictive Behaviors, 2008; 33 :16021605.

5. Samuel M.C, Doherty P.M, Bulterys M dan Jenison SA. Association between heroin use, needle sharing and tattoos received in prison with hepatitis $B$ dan $C$ positivity among street-recruited injecting drug users in New Mexico, USA. Cambridge University Press : Epidemiol.Infect,2001; 127: 475-484.

6. Thesis Soitawati. Faktor-faktor yang mempengaruhi putus berobat pasien pengguna narkoba suntik di klinik rumatan metadon puskesmas kecamatan Jatinegara Jakarta Timur dan Puskesmas Kecamatan Gambir Jakarta Pusat Tahun 2007-2008. Depok : FKM UI, 2009

7. Bouhnik Anne-Deborah, et al. Drug Injection among HIV-infected injecting drug users. Addictive Behaviors, 2004;29:1189-1197

8. Steensma Collin, Boivin Jean-Francois, Blais Lucie dan Roy, Elise. Cessation of Injecting drug use among street-based youth. Oxford University Press : Journal of Urban Health : Bulletin of New York Academy, $2005 ; 82: 4$

9. Kleinbaum David G dan Klein Mitchel. Survival analysis : a self learning text (2ed). USA : Springer Science+Business Media, Inc, 2005.

10. Becker Marshall $\mathrm{H}$. The health belief model and personal health behavior. New Jersey : Charles B. Slack, Inc, 1974.

11. Doweiko Harold E. Concept of chemical dependency (Fifth edition). Wadswoorth. USA, 2002.

12. Carroll Charles R. Drugs in modern society (fifth edition). USA: McGrawHill Higher Education, 2000.

13. Blume Arthur W. Treating Drug Problem. USA : John Wiley \& Sons,Inc, 2005.

14. Thesis Sawitri Harvina. Determinan berhenti pakai narkoba suntik (Studi Penyalahgunaan Narkoba di 17 Provinsi Tahun 2008). Depok : FKM UI, 2012. 
